\title{
PRODUCTION OF BIOSURFACTANT BY HYDROCARBON DEGRADING RHODOCOCCUS RUBER AND RHODOCOCCUS ERYTHROPOLIS
}

\author{
Flávio Correa Bicca ${ }^{1,2}$; Leonardo Colombo Fleck²; Marco Antônio Záchia Ayub ${ }^{1,2^{*}}$ \\ ${ }^{1}$ Departamento de Bioquímica and ${ }^{2}$ Instituto de Ciência e Tecnologia de Alimentos. Universidade Federal do \\ Rio Grande do Sul-UFRGS, Porto Alegre, RS, Brasil.
}

Submitted: March 02, 1999; Returned to authors for corrections: June 29, 1999; Approved: July 30, 1999.

\begin{abstract}
There is world wide concern about the liberation of hydrocarbons in the environment, both from industrial activities and from accidental spills of oil and oil-related compounds. Biosurfactants, which are natural emulsifiers of hydrocarbons, are produced by some bacteria, fungi and yeast. They are polymers, totally or partially extracellular, with an amphipathyc structure, which allows them to form micelles that accumulate at the interface between liquids of different polarities such as water and oil. This process is based upon the ability of biosurfactants to reduce surface tension, blocking the formation of hydrogen bridges and certain hydrophilic and hydrophobic interactions. The ability of biosurfactant production by five strains of Rhodococcus isolated from oil prospecting sites was evaluated. Surface tension measurement and emulsifying index were used to quantify biosurfactant production. The influence of environmental conditions was also investigated $-\mathrm{pH}$, temperature, medium composition, and type of carbon source - on cell growth and biosurfactant production. Strain AC 239 was shown to be a potential producer, attaining $63 \%$ of emulsifying index for a Diesel-water binary system. It could be used, either directly on oil spills in contained environments, or for the biotechnological production of biosurfactant.
\end{abstract}

Key words: biosurfactant, hydrocarbon degradation, Rhodococcus $s p$

\section{INTRODUCTION}

The annual release of crude oil in the oceans is estimated to be around 1.7 to 1.8 metric tons (11) and the impact of this pollution can be severe environmental imbalance. The microbial biodegradation of hydrocarbons appears to be a promising tool to control such pollution, and it is not surprising that much research is in under progress to study the biochemistry and the genetics involved in this activity (4). Biosurfactants are directly involved in the process of oil and oil-related product removal from the environment. These bio-molecules are produced by several strains of bacteria and fungi. Bushnell and Haas (1) were among the first to demonstrate bacterial production of biosurfactants by isolating Corynebacterium simplex and strains of Pseudomonas in a mineral media, containing either kerosene, mineral oil or paraffin.

The genus Rhodococcus - bacteria with a diverse and efficient metabolism - is also able to transform, biodegrade or utilize as carbon source several hydrophobic compounds such as hydrocarbons, chlorinated phenols, steroids, lignin, coal and crude

\footnotetext{
* Corresponding author. Mailing address: Instituto de Ciência e Tecnologia de Alimentos, BIOTECLAB - UFRGS, Av. Bento Gonçalves, 9500, Caixa Postal 15090, CEP 91501-970, Porto Alegre, RS, Brasil. Fax (+5551) 316-7048. E-mail: mazayub@vortex.ufrgs.br
} 
oil. This capability could be of great commercial and industrial importance.

Rhodococcus are aerobic, Gram-positive, nonmotile, nocardioform actinomycetes, with a life cycle alternating between cocci and small rods, sometimes showing small filamentous projections (7).

Diesel oil is an excellent model for studying hydrocarbon biodegradation, since it is constituted of a variety of these molecules, such as paraffin, olefins, naphtha and aromatic compounds. The molecular weight of the hydrocarbons present in Diesel is also variable, with molecules containing from 9 to 20 carbon atoms. The ASTM, through the standards issued in ASTM D 975, classifies three different types of Diesel, 1-D, 2-D and 4-D. In Brazil, however, there is only one classification, issued by standard 04 of The National Oil Council. Brazil is a large diesel producer and user, and there have been several reports on Diesel spills in the environment, besides other pollution problems related to the extensive use of this fuel (2).

The aims of this work are to identify suitable bacterial strains for biosurfactant production, and to study their metabolism in order to obtain these biomolecules on a commercial scale, to be safely used in pollution control.

\section{MATERIALS AND METHODS}

Bacterial strains. The following strains were obtained from the alkanotrophic bacteria collection of The Microbial Ecology and Genetics Institute of The Science Academy of Ural Division, Russia: AC 74 Rhodococcus ruber, AC 87 Rhodococcus ruber, AC 239 Rhodococcus ruber, AC 265 Rhodococcus erythropolis, AC 272 Rhodococcus erythropolis. As negative controls, two biosurfactant non producing strains of Escherichia coli and Bacillus cereus were used.

Media used and growth conditions. Cultures of bacteria were maintained on either nutrient agar, or Bushnell and Haas mineral agar, MMBH, (1) containing $1 \%(\mathrm{v} / \mathrm{v})$ of Diesel, previously sterilized by filtration through a Millipore membrane with pore size of $0.22 \mu \mathrm{m}$. Experiments on growth optimisation and biosurfactant production were performed using three different mineral media: $\mathrm{M} 1$, containing $\mathrm{MgSO}_{4}$ $0.20 \mathrm{~g} / 1 ; \mathrm{CaCl}_{2} 0.02 \mathrm{~g} / \mathrm{l} ; \mathrm{KH}_{2} \mathrm{PO}_{4} 1.0 \mathrm{~g} / \mathrm{l} ; \mathrm{NH}_{4} \mathrm{NO}_{3}$ $1.0 \mathrm{~g} / 1 ; \mathrm{K}_{2} \mathrm{HPO}_{4} 1.0 \mathrm{~g} / 1 ; \mathrm{NaNO}_{3} 3.0 \mathrm{~g} / 1 ;$ lactose $1.0 \mathrm{~g} /$ 1; Diesel $1 \%(\mathrm{v} / \mathrm{v}) ; \mathrm{ZnSO}_{4} .7 \mathrm{H}_{2} \mathrm{O} 0.525 \mathrm{~g} / 1 ; \mathrm{Mn}$
$\mathrm{SO}_{4} \cdot 4 \mathrm{H}_{2} \mathrm{O} \quad 0.20 \mathrm{~g} / 1 ; \mathrm{CuSO}_{4} .5 \mathrm{H}_{2} \mathrm{O} \quad 0.705 \mathrm{~g} / 1$; $\mathrm{NaMoO}_{4} \cdot 2 \mathrm{H}_{2} \mathrm{O} 0.015 \mathrm{~g} / 1 ; \mathrm{CoCl}_{2} .6 \mathrm{H}_{2} \mathrm{O} 0.20 \mathrm{~g} / 1$; $\mathrm{H}_{3} \mathrm{BO}_{3} 0.015 \mathrm{~g} / 1 ; \mathrm{FeSO}_{4} .7 \mathrm{H}_{2} \mathrm{O} 0,01 \mathrm{~g} / 1 ; \mathrm{M} 2$, containing $\mathrm{NaNO}_{3} 7.0 \mathrm{~g} / \mathrm{l} ; \mathrm{K}_{2} \mathrm{HPO}_{4} 1.0 \mathrm{~g} / 1 ; \mathrm{KH}_{2} \mathrm{PO}_{4}$ $0.50 \mathrm{~g} / \mathrm{l} ; \mathrm{KCl} 0.10 \mathrm{~g} / \mathrm{l} ; \mathrm{MgSO}_{4} \cdot 7 \mathrm{H}_{2} \mathrm{O} 0.50 \mathrm{~g} / \mathrm{l} ; \mathrm{CaCl}_{2}$ $0.01 \mathrm{~g} / \mathrm{l} ; \mathrm{FeSO}_{4} .7 \mathrm{H}_{2} \mathrm{O} 0.01 \mathrm{~g} / \mathrm{l}$; yeast extract $0.10 \mathrm{~g} /$ 1; Diesel $1 \%$ (v/v); and M3, containing $\mathrm{MgSO}_{4} 0.20 \mathrm{~g} /$ 1; $\mathrm{CaCl}_{2} 0.02 \mathrm{~g} / \mathrm{l} ; \mathrm{KH}_{2} \mathrm{PO}_{4} 2.0 \mathrm{~g} / \mathrm{l} ; \mathrm{NH}_{4} \mathrm{NO}_{3} 2.0 \mathrm{~g} / \mathrm{l}$; $\mathrm{FeCl}_{3} .6 \mathrm{H}_{2} \mathrm{O} 0.05 \mathrm{~g} / 1 ; \mathrm{K}_{2} \mathrm{HPO}_{4} 2.0 \mathrm{~g} / 1$; glucose $10.0 \mathrm{~g} /$ 1 ; and Diesel $1 \%(\mathrm{v} / \mathrm{v})$. All chemicals were of analytical grade.

Diesel used in the experiments. Standard Diesel, without additives, was obtained directly from Petrobrás “Alberto Pasqualini” Oil Refinery, Canoas, RS, Brazil.

Culture conditions. Cultures (in flasks of $125 \mathrm{ml}$ with $30 \mathrm{ml}$ of medium) were inoculated with $5-10 \%$ volume aliquot of a overnight preculture grown for 48 hours, and incubated at $37^{\circ} \mathrm{C}, 200 \mathrm{rpm}$, in a rotatory shaker. Experiments were carried out in triplicate. Microbial growth was quantified by the technique of Miles and Misra (14).

Measurement of surface tension. The change in surface tension of cultures was evaluated by using a Leconde Du Nouy tensiometer. Samples were prepared by centrifuging at $10,000 \mathrm{~g}$ for $20 \mathrm{~min}$, and using the supernatant for the assay.

Emulsification index (E24). E24 of culture samples was determined by adding $2 \mathrm{ml}$ of hydrocarbon to the same amount of culture, mixing with a vortex for $2 \mathrm{~min}$, and leaving to stand for 24 hours. The E24 index is given as percentage of height of emulsified layer $(\mathrm{mm})$ divided by total height of the liquid column (mm) (10).

Carbohydrate assay. Carbohydrate concentration was quantified by the method of Dubois (6). A volume of $0.5 \mathrm{ml}$ of cell supernatant was mixed with $0.5 \mathrm{ml}$ of $5 \%$ phenol solution and $2.5 \mathrm{ml}$ of sulfuric acid, and incubated for $15 \mathrm{~min}$ before measuring absorbance at $490 \mathrm{~nm}$.

Haemolytic activity. Bacterial strains were tested for haemolytic activity by plating cells onto blood agar and incubated at $37^{\circ} \mathrm{C}$ for 48 hours.

Antibiotic resistance. Resistance to antibiotics (8) was determined by using Sensi-Discs (Cefan Diagnóstica Ltd.) and nutrient agar according to the instructions of the manufacturer. Isolates were tested for sensitivity to carbenicillin $(100 \mu \mathrm{g})$, chloramphenicol $(30 \mu \mathrm{g})$, penicillin (10 UI), tetracycline $(30 \mu \mathrm{g})$, ampicillin $(10 \mu \mathrm{g})$, streptomycin $(10 \mu \mathrm{g})$, erythromycin $(15 \mu \mathrm{g})$. 


\section{RESULTS AND DISCUSSION}

\section{Microbial growth on Diesel as sole carbon} source. The first set of experiments was a simple growth test on solid medium to allow for a fast strain selection. The three $R$. ruber strains, AC 74, AC 87 and AC 239, showed much better and faster growth than $R$. erythropolis on solid MMBH incubated at $37^{\circ} \mathrm{C}$ for 96 hours and they were, therefore, selected to be used in the subsequent experiments. Control strains (Escherichia coli and Bacillus cereus), did not grow or produced any biosurfactant as measured by the methods of E24 and surface tension. All five strains were tested for haemolytic activity, which is regarded by some authors as indicative of biosurfactant production and used as a rapid method for bacterial screening $(3,10,12)$. None of strains showed any haemolytic activity, indicating that the use of this rapid method could lead to reduced numbers of selected strains and potential losses of important active microorganisms. None of the Rhodococcus strains showed any resistance towards the antibiotics tested (ampicillin, tetracycline, penicillin, erythromycin, chloramphenicol, and streptomycin). The lack of haemolytic activity and antibiotic resistance suggests that these strains might be safely used in field experiments.

Microbial physiology. The three selected strains of $R$. ruber grown in Bushnell and Haas medium were evaluated for biosurfactants production and efficient Diesel emulsification. Strain AC 239 showed faster growth and higher E24 and surface tension reduction, although all strains were able to grow and produce biosurfactants (results not shown). AC 239 strain was selected for optimisation of experiments.

One important feature in scaling up a biotechnological process is the design of culture media. Three different, inexpensive growth inducers were tested: lactose $1.0 \mathrm{~g} / 1$ (M1), yeast extract $0.10 \mathrm{~g} /$ 1 (M2), and glucose 10.00 g/l (M3). Figs. 1, 2 and 3 show experiments results. M2, containing yeast extract produced in laboratory (16), was more important for cell metabolism than the additional carbon sources tested. Cells growing in M2 also produced more biosurfactant, as indicated by E24 and surface tension when compared to the other media. These results are in accordance with the work of Iqbal et al. (10), who demonstrated an enhancement in biosurfactant production, when growing Pseudomonas aeruginosa in Bushnell and Hass medium with heptadecane as the sole carbon source.

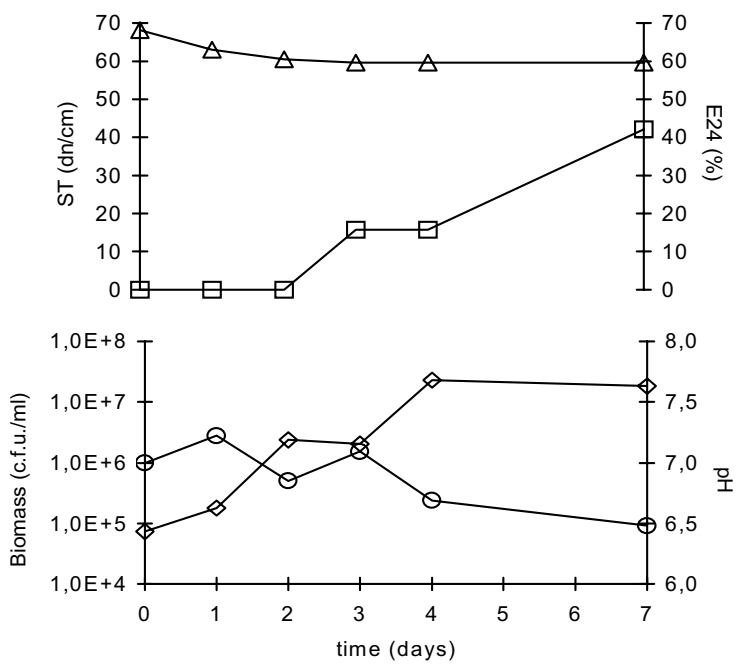

Figure 1 - Growth of Rhodococcus AC 239 in medium M1. Initial $\mathrm{pH} 7.0,37^{\circ} \mathrm{C}, 200 \mathrm{rpm}, 1 \%$ Diesel (v/v). $\Delta$ - surface tension, ST, (dynes/cm), $\square-\mathrm{E} 24,(\%), \diamond-$ Biomass (cells/ml), O $-\mathrm{pH}$.
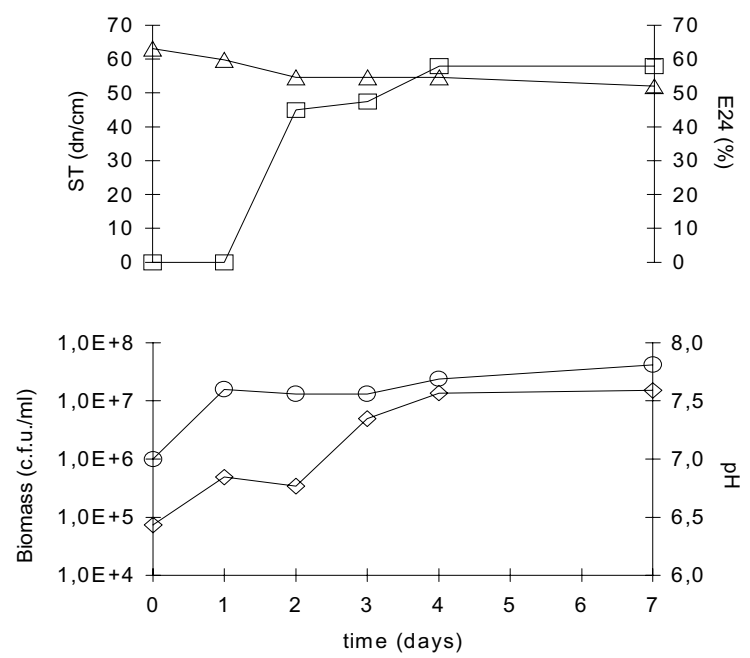

Figure 2 - Growth of Rhodococcus AC 239 in medium M2. Initial $\mathrm{pH} 7.0,37^{\circ} \mathrm{C}, 200 \mathrm{rpm}, 1 \%$ Diesel (v/v). $\Delta$ - surface tension, ST, (dynes/cm), $\square-\mathrm{E} 24,(\%), \diamond-$ Biomass (cells/ml), O - pH.

The effects of temperature $\left(30,37\right.$, and $\left.40{ }^{\circ} \mathrm{C}\right), \mathrm{pH}$ (6.0, 7.0, and 8.0), and Diesel concentration (1 to $4 \% \mathrm{v} / \mathrm{v})$, were determined in medium M2. Results presented in Fig. 4 show maximum values for biomass production and E24. The best environmental conditions for $R$. ruber AC 239 growing in M2 were $37^{\circ} \mathrm{C}, 200 \mathrm{rpm}$, initial pH 7.0, and $1 \%$ Diesel (v/v). These conditions can be used to further optimise biosurfactant production and make it economically 

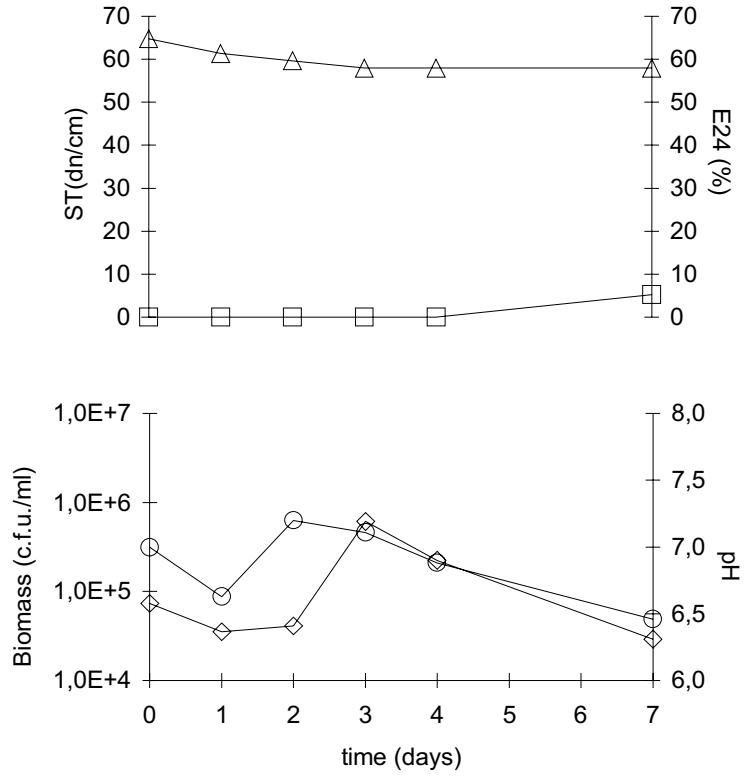

Figure 3 - Growth of Rhodococcus AC 239 in medium M3. Initial $\mathrm{pH} 7.0,37^{\circ} \mathrm{C}, 200 \mathrm{rpm}, 1 \%$ Diesel (v/v). $\Delta$ - surface tension, ST, (dynes/cm), $\square-\mathrm{E} 24,(\%), \diamond-$ Biomass (cells/ml), O - pH.
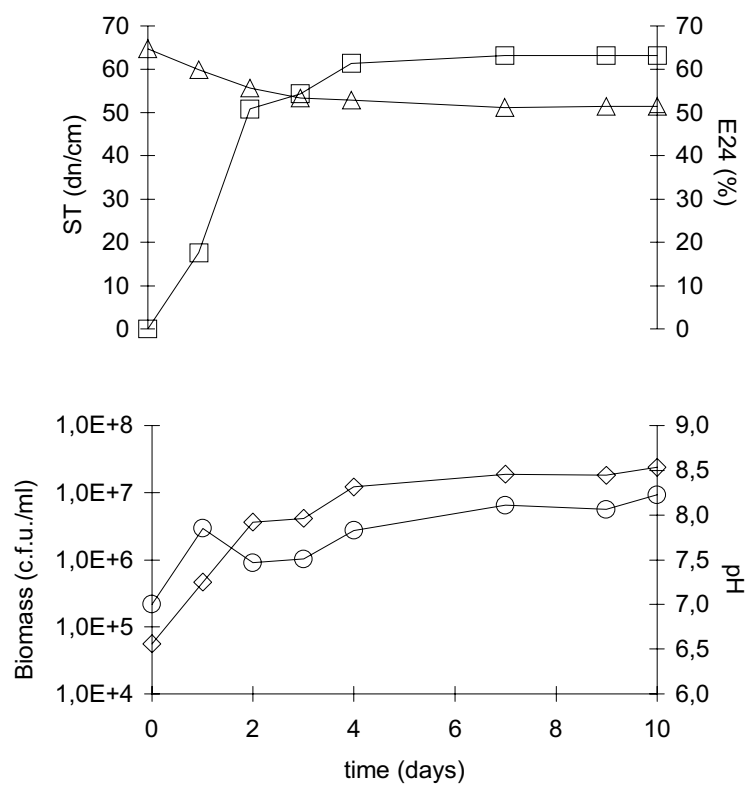

Figure 4 - Growth and biosurfactant production of Rhodococcus AC 239 in $\mathrm{M} 2$ at $\mathrm{pH} 7.0,37^{\circ} \mathrm{C}, 200 \mathrm{rpm}$, and 1\% Diesel (v/v). $\Delta$ - surface tension, ST, (dynes/cm), $\square-$ E24, (\%), $\diamond$ - Biomass (cells/ml), O $-\mathrm{pH}$.

acceptable. Maximum values obtained for surface tension reduction were around 20 dynes $/ \mathrm{cm}$, comparable to findings by other authors $(4,15)$, but not economically competitive when compared to recommended values of at least 40 dynes/cm (13). Virtually all emulsifying activity of cultures was associated to cell fraction (Fig. 6). As was shown also by Hafesburg et al. (9), for Rhodococcus sp. growing on hexadecane. The yield of biosurfactant could almost certainly, therefore, be improved by lysing the cells prior to harvest.

Fig. 5 shows the increase in carbohydrate concentration in the culture medium when strain AC 239 was grown on Diesel. Since there was no carbohydrate in the medium, its appearance and increase along growth might be due to the nature of the biosurfactant released by Rhodococcus ruber, even in small amounts, since most of emulsifying activity was associated to cell. Previous research has shown that most of biosurfactant produced by Rhodococcus species is a glycolipid-type molecule (17), which further corroborates our findings.

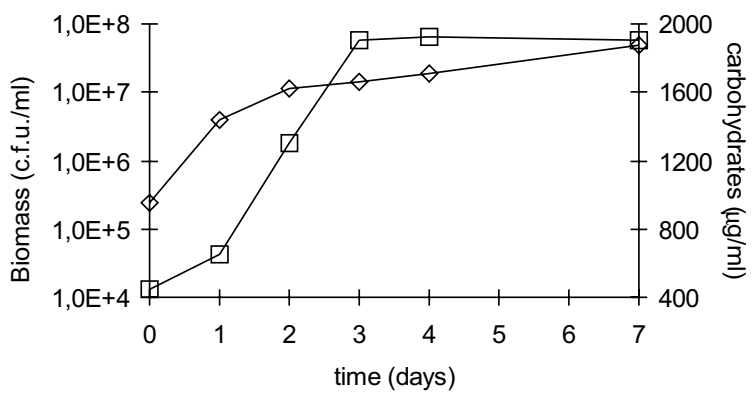

Figure 5 - Carbohydrates concentration in supernatants of Rhodococcus AC 239 cultures in M2. Initial pH 7.0, $37^{\circ} \mathrm{C}$, $200 \mathrm{rpm}, 1 \% \operatorname{Diesel}(\mathrm{v} / \mathrm{v}) . \square$ - carbohydrate $(\mu \mathrm{g} / \mathrm{ml}), \diamond$ - biomass (cells/ml).

Capability of AC 239 to emulsify other hydrocarbons. Table 1 summarises results obtained for Rhodococcus AC 239 growing on several hydrocarbon sources. The results demonstrated that this bacterium was able to grow on all oil related products as sole carbon source, showing variations in the morphological appearance of the cells. There was, apparently correlation between the molecular size of the C-hydrocarbon chain and emulsion formation. The results are particularly interesting with respect to combusted lubricant oil, which is a gas station waste, produced in large amounts. This oil residue is a potential pollution source, besides being an inexpensive potential substrate for industrial scale production of biosurfactant. Although cultures growing as clumps produced biosurfactants, as 
demonstrated by results shown in Table 1 and Fig. 6, their E24 values were always 20 to $50 \%$ lower than values for cultures where only free cells were present. These observations suggest that this late form of cell growth should be promoted in an industrial process for surfactant bio-production.

Table 1 - Growth characteristics of $R$. ruber AC 239 on different hydrocarbon sources. Medium M2, $37{ }^{\circ} \mathrm{C}, 200 \mathrm{rpm}, \mathrm{pH}$ 7.0, and 7-days cultivation.

\begin{tabular}{lccc}
\hline Hydrocarbon & Growth in & Morphological & Final \\
source & 7 days & appearance of colonies & $\mathrm{pH}$
\end{tabular}

\begin{tabular}{lcccc}
\hline & & Clumps & Secretion & \\
\hline Petrol & + & - & + & 7.05 \\
Kerosene & + & + & - & 7.18 \\
Heptane & + & - & + & 7.03 \\
Pentane & + & - & + & 7.04 \\
Benzene & + & - & + & 7.03 \\
Diesel & + & + & + & 8.30 \\
Burned Lubricant oil & + & + & - & 7.71 \\
Lubricant oil & + & + & - & 8.04 \\
\hline
\end{tabular}

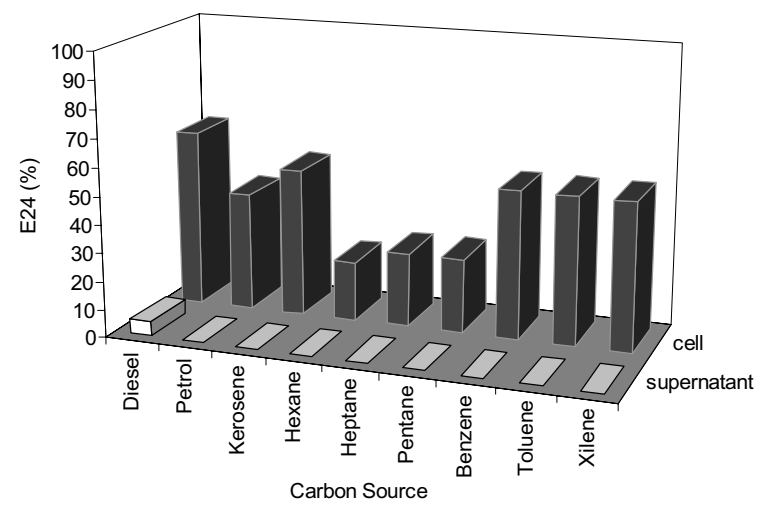

Figure 6 - Emulsifying index (E24) with different hydrocarbon for cell and supernatant fractions of $R$. ruber AC239 in medium $\mathrm{M} 2$ at $37^{\circ} \mathrm{C}, 200 \mathrm{rpm}$, and 7-days cultivation.

\section{CONCLUSIONS}

We identified three strains of Rhodococcus ruber and two of Rhodococcus erythropolis, isolated from oil wells in Russia, which were able to grow on hydrocarbons as sole carbon sources and to produce biosurfactants. One strain of $R$. ruber, AC 239, was a good biosurfactant producer and was able to grow on several hydrocarbon sources, suggesting its possible exploitation in future biotechnological processes, either directly as a field-released microorganism, or as a biosurfactant producer under controlled conditions. We optimised medium composition and culture conditions for biosurfactant production by this strain, which appears to be associated to cell wall.

Further studies are under way to scale up growth conditions and biosurfactant production in bioreactors, and to identify genes involved in the synthesis of these biomolecules.

\section{RESUMO}

\section{Produção de biossurfactantes por Rhodococcus ruber e Rhodococcus erythropolis degradadores de hidrocarbonetos}

Há uma grande preocupação mundial relacionada à liberação de hidrocarbonetos no ambiente, decorrente da atividade industrial e do derrame acidental de óleo e seus componentes relacionados. Biossurfactantes, que são emulsificadores de hidrocarbonetos, são produzidos por algumas bactérias, bolores e leveduras. São polímeros, totalmente ou parcialmente extracelulares, com uma estrutura anfipática, que formam micelas que se acumulam na interface entre líquidos de diferentes polaridades tal como água e óleo. Este processo é baseado na habilidade dos biossurfactantes em reduzir a tensão superficial, impedindo a formação de pontes de hidrogênio e certas interações hidrofílicas e hidrofóbicas. Neste trabalho, foi avaliada a produção de biossurfactantes por 5 cepas de Rhodococcus isoladas de sítios de prospecção de óleo. A medição da tensão superficial e o índice de emulsificação foram usados para quantificar a produção de biossurfactante. Investigou-se também a influência de condições ambientais - $\mathrm{pH}$, temperatura, composição do meio, e o tipo de fonte de carbono - no crescimento celular e na produção de biossurfactante. A cepa AC239 demonstrou ser uma potencial produtora de biossurfactantes, apresentando até $63 \%$ de índice de emulsificação para um sistema binário. Esta poderia ser usada diretamente em derrames de óleo no meio ambiente ou na produção biotecnológica de biossurfactante.

Palavras-chave: biossurfactante, degradação de hidrocarbonetos, Rhodococcus sp. 


\section{REFERENCES}

1. Bushnell, I.D.; Hass, H.E. Utilization of certain hydrocarbon by microorganisms. J. Bacteriol., 41: 653-658, 1941.

2. Campos, A.C.; Lemmers, H.; Peler, P.A. Ensaios realizados em derivados do Petróleo: significado e interpretação. Petróleo e Petroquímica, 17-20, 1974.

3. Carrillo, P.G.; Mardaraz, S.I.; Pitta-Alvarez; Giulietti, A.M. Isolation and section of biosurfactant producing bacteria. World J. Microbiol. Biotechnol., 12: 82-84, 1996.

4. Desai, J. D.; Banat, I.M. Microbial surfactants: evalution, types, production and future aplications. J. Sci. \& Ind. Res., 46: 440-449, 1987.

5. Desai, J. D.; Banat, I.M. Microbial production of surfactants and their commercial potential. Microbiol. Mol. Biol. Rev., 47-64, 1997.

6. Dubois, M.; Gills, K.A.; Hamilton, J.K.; Rebers, P.A.; Smith, F. Colorimetric method for determination of sugar and related substances. Anal. Chem. 28: 350-356, 1956.

7. Finnerty, W.R. The biology and genetics of the genus Rhodococcus. Ann. Rev. Microbiol., 46: 193-218, 1992.

8. Fredrickson, J. K.; Hicks, R.J.; Li, S.W.; Brockman, F.J. Plasmid incidence in bacteria from deep subsurface sediments. App. Environm. Microbiol., 2916-2923, 1988.
9. Hafesburg, D.; Hammel, R.; Claus, R.; Kleber, H.P. Extracellular microbial lipids as biosurfactants. Adv. Biochem. Eng. Biotechnol., 33: 54-88, 1986.

10. Iqbal, S.; Khalid, Z.M.; Malik, K.A. Enhanced biodegradation and emulsification of crude oil and hyperproduction of biosurfactants by gamma ray-induced mutant of Pseudomonas aeruginosa. Lett. App. Microbiol., 21: 176-179, 1995.

11. Koch, A.; Kappeli, O.; Fiechter, A.; Reiser, J. Hydrocarbon assimilation and biosurfactant production in Pseudomonas aeruginosa mutants. J. Bacteriol., 4212-4219, 1991.

12. Lin, S.C. Biosurfactants: Recent advances. J. Chem. Technol. Biotechnol., 66: 109-120, 1996.

13. Mercadé M.E.; Monleon, M.A.; André, C.; Rodón, I.; Martinez, E.; Espuny, M.J.; Manresa, A. Screening and selection of surfactant-producing bacteria from waste lubrificating oil. J. App. Bacteriol., 81: 161-166, 1996.

14. Milles, A.A.L.; Misra, S.S. The estimation of the bacterial prower of blood. J. Hyg., 38: 732-749, 1938.

15. Ochsner, U.A.; Hembach, T.; Fietcher, A. Production of rhamnolipid biosurfactants. Biotechnology, 53: 90-117, 1995.

16. Revillion, J.P.P.; Pibernat, C.; Ayub, M.A.Z. Utilização de extratos de levedura Saccharomyces cerevisea na elaboração de vinhos espumantes. Ciênc. Tecnol. Alim., 16: 196-205, 1996.

17. Singer, M.E.; Finnerty, W.R. Phisiology of biosurfactant synthesis by Rhodococcus species H13A. Can. J. Microbiol., 36: 741-745, 1990. 